\title{
Effect of potato starch on suitability for 3D printing in golden threadfin bream (Nemipterus virgatus) surimi mixture preparation
}

\author{
Hun-Seo Seo ${ }^{1}$ (D) $\cdot$ Ye-Lin Park ${ }^{1} \cdot$ Jeong-Cheol Park $^{1} \cdot$ Hyeon-Su Han ${ }^{1}$ Yoo-Seok Kang ${ }^{1}$ Ye-Hui Choi ${ }^{1}$ • \\ Su-Hyeong Kim ${ }^{1}$ - Han-Ho Kim ${ }^{1} \cdot$ So-Mi Jeong ${ }^{2} \cdot$ Woo-Sin Kang $^{1} \cdot$ Su-Ryong Kim ${ }^{1} \cdot$ Si-Hyeong Ryu $^{1}$. \\ Ji-Eun Lee ${ }^{1} \cdot X_{1}$ iaotong Xu ${ }^{1} \cdot$ Ga-Hye Lee ${ }^{2} \cdot$ Dong-Hyun Ahn ${ }^{1}$ (D)
}

\section{감자 전분의 첨가가 수리미 혼합물 제조에서 3D 프린팅 적합성에 미치는 영향}

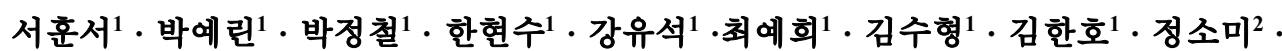
강우신 ${ }^{1}$ - 김수룡 ${ }^{1}$ - 류시형1 - 이지은 ${ }^{1}$ - 쉬시아오통 ${ }^{1}$ - 이가혜 ${ }^{2}$ - 안동현 ${ }^{1}$

Received: 8 October 2021 / Accepted: 30 October 2021 / Published Online: 31 December 2021

(C) The Korean Society for Applied Biological Chemistry 2021

\begin{abstract}
In this study, we investigated the physical properties, color values of mixtures with starch from potato in preparing a cartridge for 3D printing using golden threadfin bream (Nemipterus virgatus) surimi as raw material. The results show that the hardness and gumminess of the surimi mixture added potato starch increased but cohesiveness decreased compared to the negative control. This means that the starch makes surimi stronger texture than the negative control. After 7 days of cold storage at $4{ }^{\circ} \mathrm{C}$, for unheated surimi, firmness is increased but adhesiveness is decreased. And among physical properties of surimi stored after heating, hardness and gumminess were decreased compared to before storage. Lastly, after storage for 7 days, the hardness and gumminess of fried surimi decreased compared to fried surimi before storage. As a result of sensory evaluation, texture, elasticity scent of surimi stored after heating
\end{abstract}

Dong Hyun Ahn $(\bowtie)$

E-mail:dhahn@pknu.ac.kr

${ }^{1}$ Department of Food Science and Technology/Institute of Food Science, Pukyong National University, Busan, Republic of Korea

${ }^{2}$ Institute of Fisheries Sciences, Pukyong National University, Busan, Republic of Korea

This is an Open Access article distributed under the terms of the Creative Commons Attribution Non-Commercial License (http://creativecommons. org/licenses/by-nc/3.0/) which permits unrestricted non-commercial use, distribution, and reproduction in any medium, provided the original work is properly cited. were decreased but overall favorability was similar. Compared to the after storage, result of sensory evaluation of fried surimi, result of the before storage showed no significant differences. From these results, it is suggested that potato starch, which increases overall physical strength and have little effect on preference, can be used as an additive for golden threadfin bream surimi.

Keywords 3D printing - Golden threadfin bream - Sensory evaluation $\cdot$ Surimi Potato starch

서 론

냉동 수리미는 어류에서 내장과 뼈를 제거한 어육을 마쇄와 수 세공정을 거쳐 근장 단백질, 지질 및 비단백태 질소 화합물 등 을 제거하고, 근원섬유단백질만을 농축한 후 냉동 변성 방지제 를 혼합한 염용성 어육단백질이다[1]. 냉동 수리미는 북양 명태 자원의 이용을 위한 연구결과의 산물로서 1970년 이후를 기점 으로 하여 다양한 수산 식품을 가공하는 소재로 사용되고 있다. 수리미는 단백질 함량, 수분, 겔 강도, 육안으로 확인 가능한 이 물의 개수 및 백색도 등에 의해 품질 등급이 결정된다. 이러한 이유로 백색육 어류가 주로 수리미의 원료로 사용되어 왔고, 대 표적으로 냉수어종으로 동결 내성과 이용가치가 낮은 명태를 중 심으로 냉동 수리미 제조기술이 개발되었다[2,3]. 현재까지 수리 미의 품질특성 개선과 대체 자원을 통한 새로운 수리미를 개발 하기 위해 수행된 연구로는 산 및 알칼리공정으로 제조한 수리 
미 가열 겔의 물성[4], 혼합 인산염의 첨가가 어류 연육의 기능 적 성질에 미치는 영향[5], 산과 알칼리 $\mathrm{pH}$ 에서 어육 단백질의 용해를 이용한 수리미 제조[6], 냉동수리미의 품질과 어묵 겔강 도의 관계[7], 저급 수리미의 겔강도 증강을 위한 첨가물의 최 적화[8] 등이 보고된 바 있다.

전분은 그 이용가치가 매우 높아, 그것 자체를 이용해 음식 을 만들거나 무독성, 호화 시 발생되는 물성 등이 있어 식품에 첨가하여 안정화와 농후제 등의 역할을 하는데 이용되고 있다. 감자 전분은 1811년 미국 New England에서 전분으로 처음 생 산되었으며[9], 구황작물인 감자의 성분 중 $10-30 \%$ 를 차지하는 식물성 다당류의 일종으로 D-glucose가 수백에서 수백 만개 정 도 축합된 천연 고분자 물질이다. 또한 식품 제조에 있어서 물 성을 변화시키는 농후제 등으로 이용하는 경우가 많다. 감자전 분이 다른 전분과 구별되는 특성으로는 큰 전분 입자, 높은 순 도, 비교적 긴 아밀로오스와 아밀로펙틴 사슬의 길이, 아밀로펙 틴에 인산 에스테르기의 존재, 점성적 거동(viscosity behavior) 에 영향을 미치는 특정 양이온을 교환하는 능력, 가열과 냉각 시 걸쭉한 점탄성의 젤을 형성하는 능력이 있다[10]. 또한, 감 자전분은 높은 점도, 우수한 필름 형성력, 낮은 호화 온도의 특 징을 가지고 있고[11], 겔 형성 시 부드러움과 탄성은 좋으나 겔 강도가 약하며[12], 팽윤, 수화 된 감자전분의 입자들은 파 괴되기 쉽고 계속되는 가열과 교반에 의해 더욱 쉽게 파괴되는 경향을 가지고 있다[11]. 이러한 특성을 가진 감자 전분의 주된 역할은 호화를 통해 제품의 물성을 안정화시키는 것으로, 이는 액상형 제품이나 고체형 제품에서도 쓰이며 물성 향상제로써 우 수한 식용 첨가제이다[13].

$3 \mathrm{D}$ 프린팅 기술은 생체, 스마트 재료, 폴리머, 복합제, 금속 및 세라믹과 같은 광범위한 원료를 사용하여 고품질 완제품 생 산을 목적으로 다양한 제조 산업에서 이용하고 있다[14]. 3D 식 품 프린팅은 통상 미세 노즐을 통해 녹은 필라멘트 또는 페이 스트의 압출을 포함하고, 식품에 $3 \mathrm{D}$ 프린팅을 가장 먼저 적용 한 분야는 효모, 옥수수 시럽, 설탕, 전분, 냉동 케이트 혼합물 페이스트 압출 등이 있다[15].

$3 \mathrm{D}$ 프린팅이 가능한 식품 원료의 선정과 원료 특성에 대한 정보는 식품 $3 \mathrm{D}$ 프린팅에 있어 중요한 요소이다. 일반적으로 분쇄, 분리 단백질 및 변성 전분 등과 같이 예비 처리된 원료 가 열 안전성을 증진시켜 $3 \mathrm{D}$ 프린팅 식품 원료로 적절하다. $3 \mathrm{D}$ 프린팅 과정에서 식품 원료는 액체 또는 고체 분말 등 유동성 이 있는 상태로 공급되어야 하고, 유동성 유지를 위해 열에 의 한 가소화나 용융 상태로 냉각하여 형상을 유지시킨다. 3D 프 린팅 식품의 형태를 유지하기 위하여 일반적으로 프린팅 온도 변화, 첨가제 사용, 가역적 가공 및 겔화 등의 방법을 사용하고 있다. 또한 식품은 탄수화물, 지방 및 단백질 등 여러 성분으로 이루어져 있으므로 이와 같은 식품 성분의 조성비는 $3 \mathrm{D}$ 프린 팅 과정에서 식품의 유리전이, 용융거동 및 가소화에 절대적인 영향을 주는 것으로 알려져 있다[16-20].

식품 소재를 $3 \mathrm{D}$ 프린팅 카트리지로 이용할 경우에는 소재의 겔화가 중요한 관건인데, 전분, 잔탄 검, 구아 검, 아라비아 검, 로커스트 빈 검, 카라기난, 팩틴, 한천 등을 첨가하는 전처리 방 식으로 해결이 가능하다[21]. 육류 제품의 경우, Transglutaminase 와 베이컨 지방 등이 칠면조 고기 퓨레와 가리비 프린팅의 첨 가제로 사용된 바 있다[22]. 그리고 어류 수리미 소재에 염화나
트륨을 첨가하여 겔 물성에 미치는 영향이 연구된 바 있고[23], 알긴산을 첨가한 수리미 혼합물의 응고에 미치는 칼슘의 영향 에 대한 연구가 보고된 바 있다[24].

본 연구에서는 3D 프린팅을 위한 수리미 혼합물 제조 시, 수 리미의 물성을 조절하기 위하여 감자 전분 $(0,1,2,3 \mathrm{wt} \%)$ 을 첨가하였고, 이에 따른 물성 변화와 관능 평가를 통하여 감자 전분 첨가에 의한 수리미 혼합물의 $3 \mathrm{D}$ 프린팅 카트리지로서의 이용 가능성을 평가하였다.

\section{재료 및 방법}

\section{실험 재료}

본 실험에서 사용된 수리미는 SA급 실꼬리돔(golden threadfin bream, Nemipterus virgatus) 수리미로 KOREAN SEAFOOD사 (Busan, Korea)에서 구입하였다. 실꼬리돔 수리미는 $-30{ }^{\circ} \mathrm{C}$ 이 하의 냉동고에 저장하면서 실험에 사용하였다.

\section{시료 준비}

$-30{ }^{\circ} \mathrm{C}$ 이하에서 보관중인 냉동 실꼬리돔 수리미를 $4{ }^{\circ} \mathrm{C}$ 에서 냉 장 해동한 후, Silent cutter (ST11, ADE Co., Hamburg, Germany)에 넣고 분쇄하고, 소금((주)한주소금, Ahnsan, Korea) $1.2 \mathrm{wt} \%$, 설탕(CJ제일제당(주), Seoul, Korea) $1.5 \mathrm{wt} \%$, 인산염 혼합제제((주)MSC, Kyeongnam, Korea) $0.5 \mathrm{wt} \%$ 를 첨가하여 고기 갈이 한 후 냉수 $(40 \mathrm{wt} \%)$ 를 첨가하고 혼합하였다. 이후 감 자 전분을 $0,1,2,3 \mathrm{wt} \%$ 함량 별로 각 시료에 첨가해 약 15 분간 혼합하였다. 혼합물은 충진기(DICK $15 \mathrm{LB}, \mathrm{DICK}$ Co., Metten, Germany)에 물리적인 강한 충격을 주어 기포를 빼고 PVDC casing에 충진하여 sealing machine (PACKNER HRPS2, MAX Co., Tokyo, Japen)에서 결찰 하였다. 충진 후 항 온조(JS-WBP-170P, 20)에서 $40^{\circ} \mathrm{C}$ 조건으로 40 분간 예비 가열 하고, 열수탱크(DDW-WBT110 Co., Dongwon Scientific System, Seoul, Korea)에서 $80{ }^{\circ} \mathrm{C}$ 조건으로 50 분간 가열하였다. 이후 5 ${ }^{\circ} \mathrm{C}$ 의 수중에서 30 분간 냉각하여, 이를 가열 수리미 혼합물 시 료로 사용하였다. 또한 수리미 혼합물 시료를 $4{ }^{\circ} \mathrm{C}$ 의 냉장고에 서 7 일간 보관한 후 $180{ }^{\circ} \mathrm{C}$ 기름에서 5 분간 튀겨 튀김 수리미 의 저장성을 확인하였다.

\section{색도 측정}

감자 전분 함량 별 $[0,1,2,3 \mathrm{wt} \%]$ 가열 수리미 혼합물의 단 면을 잘라 절단면의 색도를 분광광도계(칼라메타, JC 801, Color Technosystem Co., Tokyo, Japan)로 측정하였고, 명도(Lightenss)

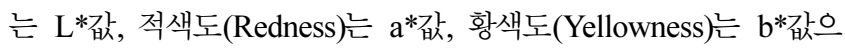
로 나타내었고, 색차(color difference)는 $\Delta \mathrm{E}$ 값으로 아래의 식을 이용하여 나타내었다. 사용한 표준색의 값은 $\mathrm{X}=92.35, \mathrm{Y}=83.92$, $Z=96.98$ 이다.

$$
\Delta \mathrm{E}=\sqrt{\Delta L^{2}+\Delta a^{2}+\Delta b^{2}}
$$

\section{물성 측정}

물성 측정은 Texture meter (T1-AT2, SMS Co., Tokyo, Japan) 를 이용하여 Lee와 Yoo의 방법[25]을 참고하여 TPA (Texture 


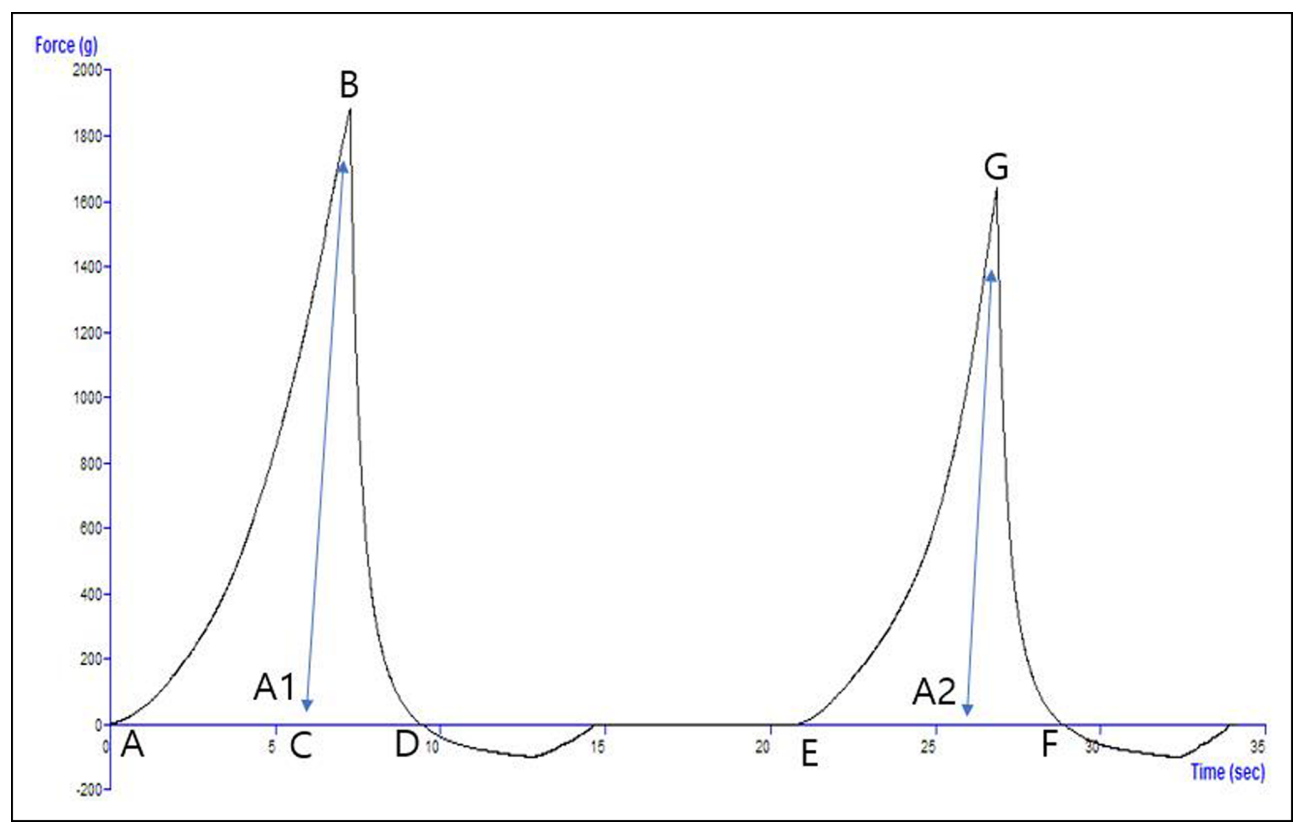

Fig. 1 Typical force-distance curve in TPA analysis [25]. TPA, texture profile analysis

Profile Analysis) 매개변수 경도(hardness), 부착성(adhesiveness), 탄력성(springiness), 응집성(cohesiveness), 검성(gumminess), 씹 힘성(chewiness) 및 복원성(resilience)을 측정하였다. 감자 전분 함량 별 가열 수리미 혼합물과 튀김 수리미 혼합물의 경우, 시 료의 지름을 $4,1.5 \mathrm{~cm}$ 로 자른 후 $\mathrm{p} / 45$ (45 mm diameter aluminum cylinder probe)를 이용하여 Test speed $(1 \mathrm{~mm} / \mathrm{s})$, Strain $(50.0 \%)$, Trigger Force $(5.0 \mathrm{~g})$ 의 조건에서 5 회 이상 측정한 후 평균값을 취하였다. 경도는 Fig. 1과 같이 가장 높은 압착감 $(\mathrm{B}, \mathrm{G})$ 을 의 미하고, 점착성은 시료가 probe에서 떨어지는 데까지 필요한 힘 ( $\mathrm{D}$ 에서 $\mathrm{E}$ 까지 걸리는 시간), 탄력성은 압착 후 다시 원래의 상 태로 돌아가려는 시료의 높이 $(\mathrm{EF} / \mathrm{AC})$, 응집성은 시료가 있는 그대로 유지하려는 면적(A2/A1)의 비율, 씹힘성은 $(\mathrm{B} \times$ 탄력성 $\times$ 응집성 $)$, 검성은 $(\mathrm{B} \times$ 응집성 $)$ 으로 나타냈다.

\section{관능평가}

관능평가는 잘 훈련된 7명의 Panel (부경대학교 식품공학과 남 4명, 여 3명. 21-25세)를 선정하여 평가 대상 수리미 혼합물의 색 (color), 냄새(smell), 비린내(fish smell), 맛(taste), 이미(abnormal taste), 조직감(texture), 경도(hardness), 탄력성(springiness) 및 종 합적 기호도(preference) 등 9가지 항목을 7점 척도로 실시하였 다(부경대학교 기관생명윤리위원회 승인번호: 1041386-202005HR-30-02). 7점 척도 중 1점은 매우 나쁘거나 낮음(extremely bad or silght), 7점은 매우 좋거나 강함(extremely good or much)으로 표시하게 하여 관능평가를 실시하였고, 시료와 시료 를 검사하는 사이에 입을 헹구어 결과값의 객관성을 높였다.

\section{통계분석}

실험을 통해 도출된 결과에 대한 통계 분석은 SAS program (ver. 9.3, SAS Institute, Inc., Cary, NC, USA)을 이용하여 실 험 처리된 값의 평균값을 분산분석을 실시한 뒤, Ducan's multiple range test 법으로 $p<0.05$ 수준에서 항목 간의 유의적 인 차이를 검증하여 판별하였다.

\section{결과 및 고찰}

\section{감자 전분 첨가 수리미 혼합물의 유동성}

감자전분을 첨가한 수리미 혼합물의 유동성을 확인한 결과, 감 자전분의 첨가량이 증가할수록 경도는 감소하는 경향이나 큰 차 이는 없었으며, 점착성은 증가하는 경향을 보였고 특히 $3 \%$ 에서 가장 높은 값으로 확인되었으나 통계상 유의성은 없었다(Table 1). 이는 감자전분이 혼합된 상태로 호화된 상태가 아니기 때문 에 물성에 큰 영향을 미치지는 않은 것으로 판단된다. 이와 같 은 특성은 토출 시에 경도가 약하고 점성이 있어야 하는 $3 \mathrm{D}$ 프 린트용의 혼합물에 적합한 특성이라고 사료된다.

$3 \mathrm{D}$ 프린팅 카트리지로서 적용할 수 있는 식품 원료는 적절 한 유동성, 점착성, 빠른 복원력 및 적절한 기계적 강도를 가져 야 노즐 끝에서 쉽게 흘러나올 수 있고 인쇄 후 모양을 유지할 수 있다. 특히 가소성 있는 식품 원료는 열가소성 고형물이거 나 연질 고형물로서 $3 \mathrm{D}$ 프린팅 과정에서 사출 가능해야 한다.

Table 1 Texture values of surimi containing different concentration of potato starch

\begin{tabular}{ccc}
\hline \hline Potato starch $(\mathrm{wt} \%)$ & Firmness & Adhesiveness \\
\hline 0 & $897.70 \pm 25.62^{\mathrm{b}}$ & $-760.58 \pm 96.76^{\mathrm{a}}$ \\
1.0 & $961.78 \pm 26.18^{\mathrm{a}}$ & $-778.76 \pm 44.66^{\mathrm{a}}$ \\
2.0 & $865.90 \pm 40.77^{\mathrm{b}}$ & $-732.96 \pm 106.78^{\mathrm{a}}$ \\
3.0 & $864.63 \pm 28.00^{\mathrm{b}}$ & $-835.75 \pm 54.57^{\mathrm{a}}$ \\
\hline
\end{tabular}

Means in the same column (a-b) bearing different superscript in sample are significantly different $(p<0.05)$ 
Table 2 Changes in color value of heated surimi containing different concentration of potato starch during cold storage for 7 days

\begin{tabular}{cccccc}
\hline \hline Storage time (day) & Potato starch (wt\%) & $\mathrm{L}^{*}$ & $\mathrm{a}^{*}$ & $\mathrm{~b}^{*}$ & $\Delta \mathrm{E}$ \\
\hline & 0 & $74.43 \pm 0.14^{\mathrm{Aa}}$ & $-0.10 \pm 0.10^{\mathrm{Ab}}$ & $2.46 \pm 0.11^{\mathrm{Aa}}$ & $24.21 \pm 0.14^{\mathrm{Ad}}$ \\
0 & 1.0 & $72.77 \pm 0.50^{\mathrm{Ad}}$ & $-0.09 \pm 0.34^{\mathrm{Ab}}$ & $1.75 \pm 0.17^{\mathrm{Ac}}$ & $26.14 \pm 0.49^{\mathrm{Aa}}$ \\
& 2.0 & $73.74 \pm 0.36^{\mathrm{Ab}}$ & $-0.05 \pm 0.15^{\mathrm{Ab}}$ & $2.13 \pm 0.16^{\mathrm{Ab}}$ & $25.21 \pm 0.34^{\mathrm{Ac}}$ \\
& 3.0 & $73.44 \pm 0.22^{\mathrm{Ac}}$ & $0.62 \pm 0.11^{\mathrm{Aa}}$ & $1.70 \pm 0.09^{\mathrm{Ac}}$ & $25.44 \pm 0.21^{\mathrm{Ab}}$ \\
\hline & 0 & $74.62 \pm 0.18^{\mathrm{Aa}}$ & $-1.22 \pm 0.15^{\mathrm{Bc}}$ & $2.50 \pm 0.16^{\mathrm{Aa}}$ & $24.20 \pm 0.17^{\mathrm{Ad}}$ \\
& 1.0 & $73.10 \pm 0.33^{\mathrm{Ad}}$ & $-0.56 \pm 0.20^{\mathrm{Bb}}$ & $1.49 \pm 0.16^{\mathrm{Bd}}$ & $25.65 \pm 0.33^{\mathrm{Ba}}$ \\
& 2.0 & $73.96 \pm 0.22^{\mathrm{Ab}}$ & $-0.19 \pm 0.15^{\mathrm{Aa}}$ & $1.84 \pm 0.12^{\mathrm{Bb}}$ & $24.81 \pm 0.21^{\mathrm{Bc}}$ \\
& 3.0 & $73.53 \pm 0.45^{\mathrm{Ac}}$ & $-0.28 \pm 0.19^{\mathrm{Ba}}$ & $1.73 \pm 0.12^{\mathrm{Ac}}$ & $25.23 \pm 0.46^{\mathrm{Ab}}$ \\
\hline
\end{tabular}

Means in the same storage period (a-d) and different storage period (A-B) with different superscript letters are significantly different $(p<0.05)$

Table 3 Texture values of heated surimi containing different concentration of potato starch during cold storage for 7 days

\begin{tabular}{ccccccccc}
\hline \hline $\begin{array}{c}\text { Storage time } \\
(\text { day })\end{array}$ & $\begin{array}{c}\text { Potato starch } \\
(\mathrm{wt} \%)\end{array}$ & $\begin{array}{c}\text { Hardness } \\
\left(\mathrm{N} / \mathrm{cm}^{2}\right)\end{array}$ & $\begin{array}{c}\text { Adhesiveness } \\
(\mathrm{N})\end{array}$ & $\begin{array}{c}\text { Springiness } \\
\left(\mathrm{cm}^{-2}\right)\end{array}$ & Cohesiveness & $\begin{array}{c}\text { Gumminess } \\
\left(\mathrm{N} / \mathrm{cm}^{2}\right)\end{array}$ & $\begin{array}{c}\text { Chewiness } \\
\left(\mathrm{J} / \mathrm{cm}^{4}\right)\end{array}$ & \begin{tabular}{c} 
Resilience \\
\multirow{4}{*}{0}
\end{tabular} \\
0 & 0 & $1955.8 \pm 158.3^{\mathrm{Ab}}$ & $-101.4 \pm 101.2^{\mathrm{Aa}}$ & $1.1 \pm 0.3^{\mathrm{Aa}}$ & $0.84 \pm 0.02^{\mathrm{Aa}}$ & $1638.2 \pm 129.2^{\mathrm{Ab}}$ & $1722.0 \pm 337.4^{\mathrm{Aa}}$ & $0.47 \pm 0.01^{\mathrm{Aa}}$ \\
& 1.0 & $2302.9 \pm 229.9^{\mathrm{Aa}}$ & $-159.8 \pm 74.0^{\mathrm{Ba}}$ & $0.9 \pm 0.0^{\mathrm{Aa}}$ & $0.82 \pm 0.02^{\mathrm{Aa}}$ & $1874.7 \pm 166.9^{\mathrm{Aab}}$ & $1762.8 \pm 180.7^{\mathrm{Aa}}$ & $0.45 \pm 0.01^{\mathrm{Ab}}$ \\
& 2.0 & $2129.8 \pm 239.2^{\mathrm{Aab}}$ & $-175.3 \pm 87.4^{\mathrm{Ba}}$ & $0.9 \pm 0.1^{\mathrm{Aa}}$ & $0.81 \pm 0.02^{\mathrm{Aa}}$ & $1731.8 \pm 175.1^{\mathrm{Ab}}$ & $1589.8 \pm 254.1^{\mathrm{Aa}}$ & $0.40 \pm 0.01^{\mathrm{Ac}}$ \\
& 3.0 & $2378.1 \pm 322.5^{\mathrm{Aa}}$ & $-101.9 \pm 47.7^{\mathrm{Ba}}$ & $0.9 \pm 0.1^{\mathrm{Aa}}$ & $0.81 \pm 0.02^{\mathrm{Aa}}$ & $1931.4 \pm 250.7^{\mathrm{Aa}}$ & $1769.7 \pm 289.9^{\mathrm{Aa}}$ & $0.41 \pm 0.01^{\mathrm{Ac}}$ \\
\hline \multirow{4}{*}{7 days } & 0 & $1899.9 \pm 136.1^{\mathrm{Aa}}$ & $-117.6 \pm 77.2^{\mathrm{Aa}}$ & $1.0 \pm 0.0^{\mathrm{Aa}}$ & $0.84 \pm 0.01^{\mathrm{Aab}}$ & $1599.3 \pm 124.7^{\mathrm{Aa}}$ & $1513.6 \pm 118.0^{\mathrm{Aa}}$ & $0.48 \pm 0.01^{\mathrm{Aa}}$ \\
& 1.0 & $1902.1 \pm 351.3^{\mathrm{Aa}}$ & $-90.8 \pm 73.4^{\mathrm{Aa}}$ & $0.9 \pm 0.1^{\mathrm{Aa}}$ & $0.85 \pm 0.01^{\mathrm{Aa}}$ & $1623.0 \pm 299.6^{\mathrm{Aa}}$ & $1503.7 \pm 344.8^{\mathrm{Aa}}$ & $0.49 \pm 0.01^{\mathrm{Aa}}$ \\
& 2.0 & $1936.2 \pm 192.6^{\mathrm{Aa}}$ & $-75.7 \pm 40.9^{\mathrm{Aa}}$ & $1.0 \pm 0.0^{\mathrm{Aa}}$ & $0.83 \pm 0.02^{\mathrm{Ab}}$ & $1608.3 \pm 128.6^{\mathrm{Aa}}$ & $1523.9 \pm 108.9^{\mathrm{Aa}}$ & $0.42 \pm 0.01^{\mathrm{Ab}}$ \\
& 3.0 & $2229.3 \pm 301.3^{\mathrm{Aa}}$ & $-61.9 \pm 13.8^{\mathrm{Aa}}$ & $1.0 \pm 0.0^{\mathrm{Aa}}$ & $0.82 \pm 0.02^{\mathrm{Ab}}$ & $1826.9 \pm 218.4^{\mathrm{Aa}}$ & $1733.0 \pm 195.2^{\mathrm{Aa}}$ & $0.43 \pm 0.01^{\mathrm{Ab}}$ \\
\hline
\end{tabular}

Means in the same storage period (a-c) and different storage period (A-B) with different superscript letters are significantly different $(p<0.05)$

또한 원료의 점착성은 bed와 먼저 사출된 원료가 잘 부착되어 적층을 가능하게 한다. 따라서 효율적인 3D 프린팅을 위해서는 적절한 유동성과 점착성, 기계적 강도 및 빠른 복원성과 같은 특성을 충족하기 위한 식품 성분의 전처리가 매우 중요하다[26].

냉장 저장에 따른 감자 전분 첨가 수리미 혼합물의 색도 변화 감자 전분 첨가에 따른 $[0-3,1 \mathrm{wt} \%$ 간격] 가열 수리미 혼합물 의 색도 변화는 Table 2 와 같다. 명도의 경우 감자 전분 무첨 가군이 74.43 으로 가장 높은 값을 보였고, 감자 전분 함량이 $1.0 \mathrm{wt} \%$ 일 때 72.77 로 가장 낮았다. 적색도는 감자 전분 함량 이 $3 \mathrm{wt} \%$ 에서 0.62 으로 가장 높은 값을 나타냈고, 무첨가군에 서 가장 낮은 값을 나타냈다. 이는 어느 정도 색도를 가지고 있 는 감자 전분의 첨가량이 증가함에 따른 것으로 여겨진다. 황 색도의 경우 감자 전분 무첨가군에서 2.46 으로 가장 높은 값을 보였고, 색차의 경우 감자 전분 무첨가군에서 가장 낮은 값을 나타냈으며 감자 전분 $1.0 \mathrm{wt} \%$ 함량일 때 가장 높은 값을 나 타내었다. 이는 Liu 등[27]의 연구에서 감자 전분이 수리미 혼 합물의 색도에 영향을 주는 결과와 유사한 경향을 보였다.

감자 전분을 첨가한[0-3, $1 \mathrm{wt} \%$ 간격] 수리미 혼합물을 가열 하고, $4^{\circ} \mathrm{C}$ 에서 7 일간 저장한 후 색도 변화를 확인한 결과(Table $2)$, 명도는 저장 0 일차와 마찬가지로 감자 전분 무첨가군에서 가장 높은 값을 보였고, 저장에 따른 유의한 변화는 관찰되지 않았다. 적색도는 $2 \mathrm{wt} \%$ 첨가군에서 가장 높은 값을 보였고, 0 , $1,3 \mathrm{wt} \%$ 첨가군에서 저장에 따른 유의한 감소가 확인되었다. 황색도의 경우 저장 0 일차와 마찬가지로 무첨가군에서 가장 높
은 값을 보였고, $1,2 \mathrm{wt} \%$ 첨가군에서 저장에 따른 유의한 감 소를 보였다. 색차 또한 저장 0 일차와 마찬가지로 $1 \mathrm{wt} \%$ 첨가 군에서 가장 높은 값으로 확인되었고, $1,2 \mathrm{wt} \%$ 첨가군에서 저 장에 따른 유의한 감소를 나타냈다.

\section{냉장 저장에 따른 감자 전분 첨가 가열 수리미 혼합물의 물성 변화}

감자 전분 함량[0-3, $1 \mathrm{wt} \%$ 간격]에 따른 실꼬리돔 수리미 혼 합물의 저장 중 물성 변화는 Table 3 과 같다. 저장 0 일차 가열 수리미의 경우, 경도는 감자 전분 첨가군이 무첨가군 $(1,955.8)$ 에 비해 유의적으로 증가하였고, $3.0 \mathrm{wt} \%$ 첨가군이 2378.1 로 가장 높은 값을 보였다. 검성 또한 $3.0 \mathrm{wt} \%$ 감자 전분 첨가군 $(1,931.4)$ 이 무첨가군 $(1,638.2)$ 에 비해 유의적으로 증가하는 것으 로 확인되었다. 반면 부착성, 탄력성, 응집성, 씹힘성 및 복원성 에서는 감자 전분 첨가군과 무첨가군 사이에 유의적인 차이가 없었다. Yang과 Park[28]은 낮은 농도의 감자와 옥수수 전분은 수리미 겔 강도를 효과적으로 증가시킬 수 있음을 보고했고, Campo와 Tovar[29]는 밀 전분 함량이 높을수록 알래스카 폴락 수리미 겔의 점탄성 네트워크가 더 강하다고 보고한 바 있다. 전분의 첨가는 재료의 팽창과 수분 보유로 이어질 수 있어 겔 강도를 향상시키고 가공비용을 절감할 수 있을 것으로 사료된다. 7일간 냉장 저장 후 감자 전분 함량에 따른 가열 수리미 혼합 물의 물성 변화를 확인한 결과, 냉장 저장한 수리미 혼합물의 물성 변화는 저장 전과 비교하여 유의적인 차이가 없었다. 곡 물 전분(보리, 흑미, 수수, 통밀, 메밀)을 첨가한 소시지를 만든 
Table 4 Texture values of fried surimi containing different concentration of potato starch during cold storage for 7 days

\begin{tabular}{|c|c|c|c|c|c|c|c|}
\hline $\begin{array}{l}\text { Storage time } \\
\text { (day) }\end{array}$ & $\begin{array}{l}\text { Potato starch } \\
\quad(w t \%)\end{array}$ & $\begin{array}{c}\text { Hardness } \\
\left(\mathrm{N} / \mathrm{cm}^{2}\right)\end{array}$ & $\begin{array}{c}\text { Adhesiveness } \\
\text { (N) }\end{array}$ & $\begin{array}{l}\text { Springiness } \\
\left(\mathrm{cm}^{-2}\right)\end{array}$ & Cohesiveness & $\begin{array}{c}\text { Gumminess } \\
\left(\mathrm{N} / \mathrm{cm}^{2}\right)\end{array}$ & $\begin{array}{c}\text { Chewiness } \\
\left(\mathrm{J} / \mathrm{cm}^{4}\right)\end{array}$ \\
\hline \multirow{4}{*}{0} & 0 & $421.39 \pm 33.25^{\text {Aab }}$ & $0.95 \pm 0.02^{\mathrm{ABa}}$ & $0.95 \pm 0.02^{\mathrm{Aa}}$ & $326.31 \pm 49.24^{\mathrm{Aa}}$ & $309.62 \pm 50.16^{\mathrm{Aa}}$ & $0.45 \pm 0.01^{\mathrm{Ba}}$ \\
\hline & 1.0 & $396.91 \pm 116.54^{\mathrm{Ab}}$ & $0.95 \pm 0.03^{\mathrm{Aa}}$ & $0.86 \pm 0.06^{\mathrm{Aa}}$ & $339.56 \pm 101.45^{\mathrm{Aa}}$ & $323.15 \pm 104.39^{\mathrm{Aa}}$ & $0.45 \pm 0.06^{\mathrm{Ba}}$ \\
\hline & 2.0 & $469.60 \pm 112.74^{\text {Aab }}$ & $0.93 \pm 0.01^{\mathrm{Aa}}$ & $0.77 \pm 0.06^{\mathrm{Ba}}$ & $357.05 \pm 73.90^{\mathrm{Aa}}$ & $330.15 \pm 67.43^{\mathrm{Aa}}$ & $0.34 \pm 0.06^{\mathrm{Ba}}$ \\
\hline & 3.0 & $615.55 \pm 230.32^{\mathrm{Aa}}$ & $0.93 \pm 0.03^{\mathrm{Aa}}$ & $0.70 \pm 0.15^{\mathrm{Ba}}$ & $420.03 \pm 119.08^{\mathrm{Aa}}$ & $388.78 \pm 108.70^{\mathrm{Aa}}$ & $0.41 \pm 0.08^{\mathrm{Bab}}$ \\
\hline \multirow{4}{*}{7} & 0 & $248.74 \pm 86.95^{\mathrm{Ba}}$ & $0.98 \pm 0.02^{\mathrm{Aa}}$ & $0.88 \pm 0.03^{\mathrm{Ba}}$ & $219.22 \pm 79.29^{\mathrm{Ba}}$ & $214.00 \pm 75.27^{\mathrm{Ba}}$ & $0.54 \pm 0.02^{\mathrm{Aa}}$ \\
\hline & 1.0 & $253.37 \pm 60.89^{\mathrm{Ba}}$ & $0.94 \pm 0.02^{\mathrm{Ab}}$ & $0.82 \pm 0.16^{\mathrm{Aa}}$ & $212.96 \pm 79.52^{\mathrm{Ba}}$ & $199.80 \pm 74.12^{\mathrm{Ba}}$ & $0.56 \pm 0.03^{\mathrm{Aa}}$ \\
\hline & 2.0 & $264.30 \pm 38.99^{\mathrm{Ba}}$ & $0.94 \pm 0.02^{\mathrm{Ab}}$ & $0.87 \pm 0.02^{\mathrm{Aa}}$ & $231.51 \pm 38.14^{\mathrm{Ba}}$ & $217.51 \pm 35.70^{\mathrm{Ba}}$ & $0.53 \pm 0.02^{\mathrm{Aa}}$ \\
\hline & 3.0 & $256.20 \pm 58.71^{\mathrm{Ba}}$ & $0.96 \pm 0.03^{\mathrm{Aab}}$ & $0.87 \pm 0.02^{\mathrm{Aa}}$ & $223.68 \pm 52.55^{\mathrm{Ba}}$ & $213.98 \pm 49.17^{\mathrm{Ba}}$ & $0.54 \pm 0.01^{\mathrm{Aa}}$ \\
\hline
\end{tabular}

Means in the same storage period (a-b) and different storage period (A-B) with different superscript letters are significantly different $(p<0.05)$

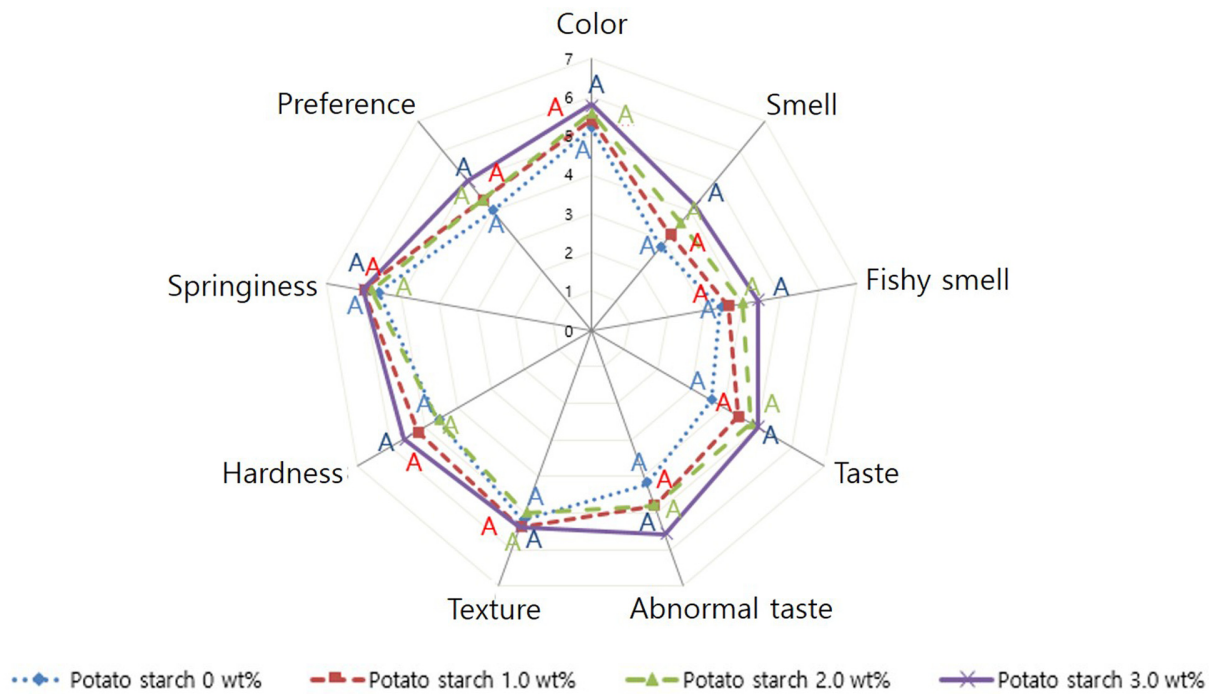

Fig. 2 Sensory evaluation of heated golden threadfin bream surimi. Values with different superscript within products are significantly different at $p<0.05$

Jang 등[30]의 연구에서는 곡물 전분을 첨가하여 냉장 저장하였 을 때 저장에 따른 노화에 의해 경도가 증가했다고 보고 하였 다. 본 연구에서는 7일간의 냉장 저장동안 감자 전분의 첨가에 따른 유의적인 물성 변화가 관찰되지 않아, 감자 전분의 첨가 가 수리미 혼합물의 품질변화에 영향을 주지 않는 것으로 판단 된다. 따라서 $3 \mathrm{D}$ 프린팅용 카트리지로써 수리미 혼합물을 냉장 하여 저장, 유통하는데 감자 전분의 첨가가 적합할 것으로 사 료된다.

\section{냉장 저장에 따른 감자 전분 첨가 튀긴 수리미 혼합물의 물성 변화}

감자 전분 함량 $[0-3,1 \mathrm{wt} \%$ 간격 $]$ 에 따른 실꼬리돔 수리미 혼 합물의 저장 중 품질변화를 확인하기 위해 저장 0 일차 튀김 수 리미와 casing 충진 상태로 7일간 냉장 저장 후 튀김 수리미의 물성 변화를 확인하였다(Table 4). 저장 0 일차 튀김 수리미의 경 우, 가열 수리미와 마찬가지로 감자 전분의 함량에 따라 경도 가 유의하게 증가하여 $3 \%$ 함량에서 615.55 로 가장 높은 값으 로 확인되었다.
7일간 냉장 저장 후 튀긴 수리미 혼합물의 경도, 검성, 씹힘 성은 0 일차에 비해 유의하게 감소하였지만, 감자 전분 함량에 따른 유의한 차이는 확인되지 않았다.

\section{감자 전분 첨가에 따른 실꼬리돔 수리미 혼합물의 관능평가}

감자전분 첨가에 따른 $[0-3,1 \mathrm{wt} \%$ 간격] 관능평가의 결과는 Fig. 2와 Table 5에 나타냈다. 감자전분의 함량이 증가됨에 따 라 냄새, 맛, 경도, 탄력성 및 종합적 호감도 등 전체적으로 증 가하는 경향을 보였으나 유의한 변화는 없었다. 이는 감자 전 분의 첨가에 다른 수리미 혼합물 겔 특성을 연구한 Kim과 Lee [31]의 결과와 유사했다. 감자 전분의 첨가에 따라 저장 시 전 분이 가진 수분을 잡아두는 특성과 점성 때문에 수리미 혼합물 겔의 질감이 강화된다고 보고 하였다. 또한 전분은 수리미 제 조 공정 중 첨가되어 가열과정을 거치면서 호화되는데, 염용성 단백질이 용출되면서 형성된 단백질의 망상구조 사이에 전분겔 이 형성되어 단단하고 탄력 있는 식감을 부여해 줄 수 있다[32]. 7일간 냉장 저장에 따른 가열 수리미 혼합물의 관능평가 결과 는 Fig. 3 과 Table 5에 나타냈다. 모든 항목에 있어서 감자 전 
Table 5 Sensory evaluation of heated surimi containing different concentration of potato starch during cold storage for 7 days

\begin{tabular}{|c|c|c|c|c|c|c|c|c|c|c|}
\hline $\begin{array}{l}\text { torage time } \\
\text { (day) }\end{array}$ & $\begin{array}{l}\text { Potato starch } \\
\quad(\text { wt } \%)\end{array}$ & Color & Smell & ishy smell & aste & $\begin{array}{c}\text { Abnormal } \\
\text { taste }\end{array}$ & Texture & Hardness & Elasticity & Preference \\
\hline \multirow{4}{*}{0 day } & 0 & $5.2 \pm 0.98^{\mathrm{Ab}}$ & $2.8 \pm 1.17^{\mathrm{Aa}}$ & $3.4 \pm 2.06^{\mathrm{Aa}}$ & $3.6 \pm 1.36^{\mathrm{Aa}}$ & $4.2 \pm 1.47^{\mathrm{Aa}}$ & $5.2 \pm 0.75^{\mathrm{Aa}}$ & $4.6 \pm 1.02^{\mathrm{Aa}}$ & $5.6 \pm 0.80^{\mathrm{Aa}}$ & $4.0 \pm 1.0 /$ \\
\hline & 1.0 & $5.4 \pm 0.80^{\mathrm{Ab}}$ & $3.2 \pm 1.17^{\mathrm{Aa}}$ & $3.6 \pm 1.62^{\mathrm{Aa}}$ & $4.4 \pm 1.20^{\mathrm{Aa}}$ & $4.8 \pm 1.33^{\mathrm{Aa}}$ & $5.4 \pm 1.20^{\mathrm{Aa}}$ & $5.2 \pm 0.75^{\mathrm{Aa}}$ & $6.0 \pm 0.63^{\mathrm{Aa}}$ & $4.4 \pm 1.20^{\mathrm{Aa}}$ \\
\hline & 2.0 & $5.6 \pm 0.80^{\mathrm{Ab}}$ & $3.6 \pm 1.20^{\mathrm{Aa}}$ & $4.0 \pm 1.79^{\mathrm{Aa}}$ & $4.8 \pm 1.60^{\mathrm{Aa}}$ & $4.8 \pm 1.33^{\mathrm{Aa}}$ & $5.0 \pm 1.10^{\mathrm{Aa}}$ & $4.6 \pm 0.49^{\mathrm{Aa}}$ & $5.8 \pm 0.75^{\mathrm{Aa}}$ & $4.4 \pm 0.80^{\mathrm{Aa}}$ \\
\hline & 3.0 & $5.8 \pm 0.98^{\mathrm{Aa}}$ & $4.2 \pm 1.17^{\mathrm{Aa}}$ & $4.4 \pm 1.50^{\mathrm{Aa}}$ & $5.0 \pm 0.89^{\mathrm{Aa}}$ & $5.6 \pm 0.80^{\mathrm{Aa}}$ & $5.4 \pm 1.20^{\mathrm{Aa}}$ & $5.6 \pm 0.80^{\mathrm{Aa}}$ & $6.0 \pm 0.63^{\mathrm{Aa}}$ & $5.0 \pm 0.89^{\mathrm{Aa}}$ \\
\hline \multirow{4}{*}{7 days } & 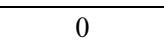 & $5.8 \pm 0.75^{\mathrm{Aa}}$ & $2.6 \pm 0.80^{\mathrm{Aa}}$ & $3.4 \pm 1.85^{\mathrm{Aa}}$ & $4.2 \pm 1.47^{\mathrm{Aa}}$ & $5.0 \pm 1.41^{\mathrm{Aa}}$ & $4.8 \pm 1.47^{\mathrm{Aa}}$ & $5.0 \pm 0.00^{\mathrm{Aa}}$ & $5.2 \pm 1.72^{\mathrm{Aa}}$ & $4.6 \pm 1.36^{\mathrm{Aa}}$ \\
\hline & 1.0 & $5.8 \pm 0.75^{\mathrm{Aa}}$ & $2.6 \pm 1.02^{\mathrm{Aa}}$ & $3.6 \pm 1.85^{\mathrm{Aa}}$ & $4.4 \pm 1.62^{\mathrm{Aa}}$ & $5.2 \pm 1.47^{\mathrm{Aa}}$ & $5.0 \pm 0.89^{\mathrm{Aa}}$ & $5.0 \pm 0.63^{\mathrm{Aa}}$ & $5.0 \pm 1.41^{\mathrm{Aa}}$ & $4.8 \pm 1.17^{\mathrm{Aa}}$ \\
\hline & 2.0 & $5.8 \pm 0.75^{\mathrm{Aa}}$ & $3.8 \pm 0.98^{\mathrm{Aa}}$ & $4.0 \pm 1.41^{\mathrm{Aa}}$ & $4.4 \pm 1.50^{\mathrm{Aa}}$ & $4.2 \pm 0.75^{\mathrm{Aa}}$ & $4.8 \pm 0.75^{\mathrm{Aa}}$ & $4.2 \pm 0.75^{\mathrm{Aa}}$ & $5.4 \pm 1.02^{\mathrm{Aa}}$ & $4.8 \pm 1.17^{\mathrm{Aa}}$ \\
\hline & 3.0 & $5.8 \pm 0.75^{\mathrm{Aa}}$ & $3.6 \pm 1.02^{\mathrm{Aa}}$ & $4.8 \pm 1.72^{\mathrm{Aa}}$ & $4.4 \pm 1.50^{\mathrm{Aa}}$ & $4.8 \pm 1.60^{\mathrm{Aa}}$ & $5.0 \pm 1.26^{\mathrm{Aa}}$ & $5.0 \pm 0.89^{\mathrm{Aa}}$ & $5.0 \pm 1.26^{\mathrm{Aa}}$ & $5.0 \pm 1.67^{\mathrm{Aa}}$ \\
\hline
\end{tabular}

Means in the same storage period (A) and different storage period (a) with different superscript letters are significantly different $(p<0.05)$

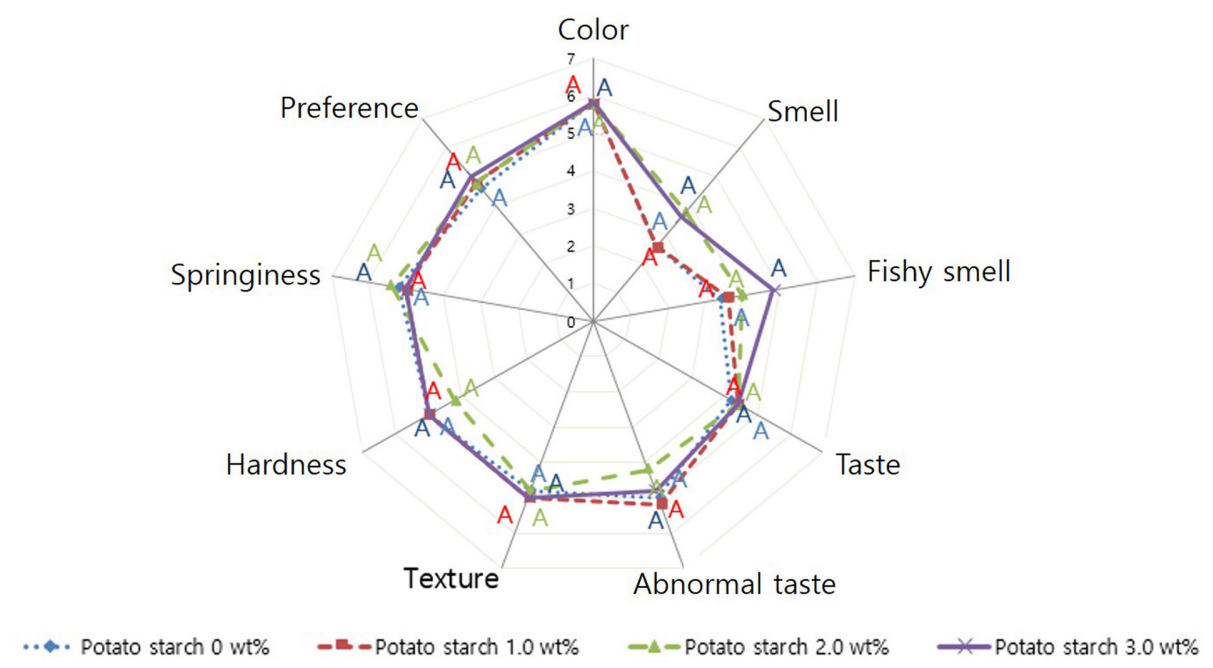

Fig. 3 Sensory evaluation of heated golden threadfin bream surimi during cold storage for 7 days. Values with different superscript within products are significantly different at $p<0.05$

분 함량의 증가에 따른 유의적인 차이는 확인되지 않았다. 또 한 색깔을 제외한 나머지 항목에서는 냉장 저장에 따른 유의한 차이가 확인되지 않았다.

\section{초 록}

본 연구에서는 $3 \mathrm{D}$ 프린팅 카트리지로서 수리미 혼합물의 가능 성을 확인하기 위하여 수리미 혼합물 제조 시 감자 전분 첨가 에 따른 물성 변화와 냉장 저장 시 나타나는 물성 변화 및 관 능평가를 측정하였다. 그 결과 색도 변화에서는 명도와 황색도 의 경우 감자 전분 무첨가군이 냉장 저장 전과 후 모두 가장 높은 값을 보였고, 적색도와 색차의 경우 감자 전분 무첨가군 이 냉장 저장 전과 후 모두 가장 낮은 값을 나타냈다. 적색도 의 경우 $0,1,3 \mathrm{wt} \%$ 첨가군에서 7 일간 냉장 저장에 따른 유의 한 감소가 확인되었고, 황색도의 경우 $1,2 \mathrm{wt} \%$ 첨가군에서 저 장에 따른 유의간 감소를 보였다. 감자 전분 첨가에 따른 물성 변화에서는 경도와 검성이 감자 전분 첨가군이 무첨가군에 비 해 증가하였다. 부착성, 탄력성, 응집성, 씹힘성 및 복원성에서
는 감자 전분 첨가군과 무첨가군 사이에 유의적인 차이가 없었 다. 냉장 저장에 따른 물성 변화에서 가열 후 7일 저장한 수리 미 혼합물의 경우 저장 전 수리미 혼합물과 비교하여 유의적인 차이가 없었다. 가열 후 7일간 냉장 저장 후 튀긴 수리미 혼합 물의 경우 경도, 검성, 씹힘성은 냉장 저장 전보다 감소하였고, 응집성, 복원성은 증가하는 결과를 확인하였다. 관능평가 결과, 감자전분의 함량이 증가함에 따라 냄새, 맛, 경도, 탄력성 및 종 합적 호감도 등 전체적으로 증가하는 경향을 보였으나 유의한 변화는 없었다. 7일간 냉장 저장한 가열 수리미는 모든 항목에 있어서 감자 전분 함량의 증가에 따른 유의적인 차이가 확인되 지 않았다. 또한 색깔을 제외한 나머지 항목에서는 냉장 저장 에 따른 유의한 차이가 확인되지 않았다. 이러한 결과를 통해 감자 전분의 첨가가 수리미 혼합물의 맛과 냄새에 영항을 주지 않고, 냉장 저장 시에도 관능 평가 상 큰 영향을 주지 않는 것 으로 확인되었다. 따라서 수리미 혼합물 제조 시 감자 전분의 첨가는 제품의 제조 및 냉장 보관 상 물성 및 품질에 영향을 주지 않는 것으로 확인된 바, 감자 전분이 $3 \mathrm{D}$ 프린팅용 수리미 제조 시 카트리지 소재로 적합하다고 사료된다. 
Keywords 감자 전분 · 관능평가 · 수리미 · 실꼬리돔 · $3 \mathrm{D}$ 프린팅

감사의 글 이 연구는 2021 년 해양수산부 재원으로 해양수산과학기술진흥 원의 지원을 받아수행되었으며, 이에 감사합니다(과제명: 미래수산식품 연구센터)

\section{References}

1. Park JW, Morrissey MT (2000) Manufacturing of surimi from light muscle fish. In: Park JW (ed) Surimi and surimi seafood. NewYork, NY, pp 23-58

2. Ahn BS, Kim BG, Jeon EB, Lee IS, Oh KS (2019) Quality characteristics by grade of commercial frozen surimi. Korean J Fish Aquat Sci 52: 555-561

3. Park HY, Cho YJ, Oh KS, Goo JK (2000) Applied fisheries processing. In: Chapter 9. Fish meat paste products. Suhyup Pub Co., Seoul, pp 264 268

4. Choi YJ, Park JD, Kim JS, Cho YJ, Park JW (2002) Rheological properities of heat-induced gels of surimi from acid and alkali process. Korean J Fish Aquat Sci 35: 309-314. doi: 10.5657/kfas.2002.35.4.309

5. Oh KS, Moon SK, Lee EH, Kim BG (1993) Study on the quality improvement of sardine surimi. Korean J Food Sci Technol 25: 327-333

6. Park JD, Jung CH, Kim JS, Cho DM, Cho MS, Choi YJ (2003) Surimi processing using acid and alkali solubilization of fish muscle protein. $\mathrm{J}$ Korean Soc Food Sci Nutr 32: 400-405

7. Kim YY, Cho YJ (1992) Relationship between quality of frozen surimi and jelly strength of kamaboko. Korean J Fish Aquat Sci. 1992. 25: 73 78

8. Suh SB, Kim TJ, Lee DS, Min JG (1999) Processing, quality stability and utilization of approved sardine surimi for surimi-based products. $\mathrm{J}$ Korean Soc Food Sci Nutr 28: 403-408

9. Singh N, Singh J, Kaur L, Sodhi NS, Gill BS (2003) Morphological, thermal and rheological properties of starches from different botanical sources. Food Chem 81: 219-231. doi: 10.1016/S0308-8146(02)00416-8

10. Vasanthan T, Bergthaller W, Driedger D, Yeung J, Sporns P (1999) Starch from Alberta potatoes: wet-isolation and some physicochemical properties. Food Res Int 32: 355-365. doi: 10.1016/S0963-9969(99) 00096-4

11. Rutenberg MW, Sorlarek D (1984) Starch derivatives: production and uses. Academic Press Inc., London, pp 324-326

12. Kim HS, Ahn SY (1997) Effect of amylose and amylopectin on the texture of Mook. Korean J Hum Ecol 6: 157-166

13. Eliasson AC (2004) Starch in food: Structure, function and applications. Woodhead Publishing Limited. BocaRation, CRC Press, NY, pp 241257

14. Shahrubudin N, Lee TC, Ramlan R (2019) An overview on 3D printing technology: technological, materials, and applications. Procedia Manuf 35: 1286-1296. doi: 10.1016/j.promfg.2019.06.089

15. Lille M, Nurmela A, Nordlund E, Metsä-Kortelainen S, Sozer N (2018) Applicability of protein and fiber-rich food materials in extrusion-based 3D printing. J Food Eng 220: 20-27. doi: 10.1016/j.jfoodeng.2017 .04 .034
16. Bhandari BR, Howes $\mathrm{T}$ (1999) Implication of glass transition for the drying and stability of dried foods. J Food Eng 40: 71-79. doi: 10.1016/ S0260-8774(99)00039-4

17. Bhandari BR, Roos YH (2003) Dissolution of sucrose crystals in the anhydrous sorbitol melt. Carbohyd Res 338: 361-367. doi: 10.1016/ S0008-6215(02)00466-4

18. Haque MK, Roos YH (2006) Differences in the physical satate and thermal behavior of spray-dried and freeze-dried lactose and lactose/ protein mixture. Innovative Food Sci Emerging Technol 7: 62-73. doi: 10.1016/j.ifset.2004.12.004

19. Roos YH (2010) Glass transition temperature and its relevance in food processing. Annu Rev Food Sci Technol 1: 469-496. doi: 10.1146/ annurev.food.102308.124139

20. Slade L, Levine H (1994) Water and glass transition-dependence of the glass transition on composition and chemical structure: Special implication for flour functionality in cookie baking. Water in Foods 22: 143-188

21. Nachal N, Moses JA, Karthik P, Anandharamakrishnan C (2019) Applications of 3D printing in food processing. Food Eng Rev 11: 123141. doi: 10.1007/s12393-019-09199-8

22. Lipton J, Arnold D, Nigl F, Lopez N, Cohen D, Norén N, Lipson H (2010) Multi-material food printing with complex internal structure suitable for conventional post-processing. SFF Symposium. pp 809-815

23. Wang L, Zhang M, Bhandari B, Yang C (2018) Investigation onfish surimi gel as promising food material for 3Dprinting. J Food Eng 220: 101-108. doi: 10.1016/j.jfoodeng.2017.02.029

24. Kim SR, Han HS, Park YL, Kang YS, Park JC, Seo HS, Choi YH, Kim SH, Jeong SM, Kang WS, Kim HH, Ryu SH, Lee JE, Xu X, Lee GH, Ahn DH (2021) Effect of calcium type on coagulation of surimi mixture with alginic acid. Korean J Fish Aquat Sci 54: 218-223. doi: 10.5657/ KFAS.2021.0218

25. Lee YS, Yoo BS (2000) Effect of compression test conditions on texture profile analysts of surimi-based products. Korean J Food Sci Technol 32: 225-230

26. He C, Zhang M, Fang Z (2020) 3D printing of food: pretreatment and post-treatment of materials. Crit Rev Food Sci Nutr 60: 2379-2392. doi: 10.1080/10408398.2019.1641065

27. Liu H, Nie Y, Chen H (2014) Effect of different starches on colors and textural properties of surimi-starch gels. Int J of Food Prop 17: 1439 1448. doi: 10.1080/10942912.2012.680224

28. Yang H, Park JW (1998) Effects of starch properties and thermalprocessing conditions on surimi-starch gels. LWT-Food Sci Technol 31: 344-353. doi: 10.1006/fstl.1997.0366

29. Campo L, Tovar C (2008) Influence of the starch content in the viscoelastic properties of surimi gels. J Food Eng 84: 140-147. doi: 10.1016/j.jfoodeng.2007.05.011

30. Jang SM, Lim JS, Cho EJ (2004) The effect of various cereal flours on quality and storage characteristics of sausage. J East Asian Soc Dietary Life 14: 265-274

31. Kim JM, Lee CM (1987) Effect of starch of textural properties of surimi gel. J Food Sci 52: 722-725. doi: 10.1111/j.1365-2621.1987.tb06711.x

32. Han JS, Lee SM (2014) Improvement of surimi seafood using modified food starches. Food Sci Ind 47: 33-38 